\title{
Evaluating the impact of PSC inspectors' professional profile: a case study of the Spanish Maritime Administration
}

\author{
Francisco J. Ravira ${ }^{1}$ - Francisco Piniella ${ }^{2}$
}

Received: 12 April 2015 / Accepted: 18 December 2015 / Published online: 7 January 2016

(C) World Maritime University 2016

\begin{abstract}
Full-scale globalisation of trade has been accompanied by a progressive liberalisation of maritime transport. The proliferation of open registries has created a situation in which Port State Control (PSC) has become much more effective than the feeble or non-existent control exercised by those States. This study has been conducted on the influence of the professional profile of inspectors on inspection results. The objective of our paper was to evaluate the impact of PSC inspectors' professional profile by conducting a case study of the Spanish Maritime Administration. The paper concludes with a discussion of the correlation between deficiencies detected and professional profiles.
\end{abstract}

Keywords Maritime safety $\cdot$ Port State Control $\cdot$ Deficiencies $\cdot$ Detentions $\cdot$ Spain

\section{Introduction}

\subsection{Characteristics of the regional agreements on Port State Control}

For more than 50 years, the International Maritime Organization (IMO) has carried out valuable work and invested a great deal of effort in implementing rules and regulations covering maritime transportation to ensure compliance with vital standards of shipping safety and marine environmental protection. The SOLAS and MARPOL Conventions

Francisco Piniella

francisco.piniella@uca.es

Francisco J. Ravira

fjravira@fomento.es

1 Algeciras Harbour Master's Office, Algeciras, Cádiz, Spain

2 Department of Maritime Studies, Universidad de Cádiz, Av. Ramón Puyol, s/n, 11202 Algeciras, Cádiz, Spain 
have been adopted in respect of $90 \%$ of the international fleet (Veiga 2002). Nevertheless, maritime regulatory regime fails to effectively address human factors and safety management challenges, as stated by Batalden and Sydnes (2013) or Kuronen and Tapaninen (2010), these being pretty much the same challenges as identified a century ago (Schröder-Hinrichs et al. 2012).

The Paris Memorandum of Understanding (MoU) on Port State Control (PSC) was adopted in response to the Amoco Cadiz disaster off the French coast in 1978. Promoted by the IMO, in recent decades, eight more agreements have been signed on PSC procedures, all of them regional in character (Psaraftis 2002). The purpose of this harmonised inspection system is to prevent substandard ships that present high risk from sailing to European and Canadian North Atlantic ports and anchorages.

The purpose of PSC is to inspect foreign vessels in national ports in order to ensure that the ship's conditions, equipment and crew comply with the requirements laid down in international conventions. The Paris MoU established two types of inspection. The first applies to all foreign vessels in member states' ports and consists of two categories: an initial inspection and a more detailed inspection. The second applies exclusively to ships considered to present a special risk and consists of only one category: an expanded inspection.

Annex XI of Directive 2009/16/EC, amended by Directive 2013/38/EU, on Port State Control, establishes the professional profile of inspectors and the qualification criteria. Basically, inspectors must have appropriate theoretical knowledge and practical experience of ships and their operation and be competent in the enforcement of conventions and the relevant PSC procedures. The requirements of becoming an inspector vary by the MoUs and across the different countries of the regime. The reality is that PSC officers can be naval architects, merchant marine captains, chief engineers, even radio officers, with sea-going experience. We hypothesised that this spectrum can generate different approaches to carry out inspections on ships. The objective of the present study was to assess the impact of PSC inspectors' professional profile on inspection results by conducting a case study of the Spanish Maritime Administration.

\subsection{Literature review}

The literature on PSC inspections is extensive, particularly as regards two aspects: the implications for Maritime Law and the policies for pollution prevention and reducing ship safety deficiencies.

Some publications, such as that by Özçayir (2004) (updated in subsequent editions), have provided a detailed analysis of the legal consequences of implementing the various PSC regimes. Others, such as those by Alcázar and Piniella (2001) and Kidman (2003), are more technical than legal in nature and much more practical, describing ship inspections and how these should be carried out. A later article by Aguilar (2008) discussed the regime of sanctions in relation to the early evolution of the PSC regime. Chatzirigopoulou (2010) has written a more general study, although this is limited to updating the legal bases of the PSC system. Since 1995, the IMO (2001) has also issued a periodically updated manual as part of a PSC model course, which has been complemented with another on procedures (IMO 2012). 
Recent years have witnessed further important contributions on different aspects of the PSC system. For example, Knapp (2004) and Knapp and Franses (2007a, b; 2008) have pioneered the application of econometrics to more accurately quantify PSC effectiveness worldwide, using binary logistic regression to identify differences between several PSC regimes. In 2007, these same researchers concluded that it was necessary to revise the frequency of inspections according to the ship risk profile, and their recommendation was subsequently implemented by the Paris MoU with the new inspection regime (NIR), which took effect from the year 2011 (Knapp and Van de Velden 2009; Knapp and Bijwaard 2009; Knapp and Franses 2010).

In a study on the role of inspectors, Knapp and Bijwaard (2009) recommended standardising inspection procedures, providing PSC officers with training and integrating the databases of various regimes, in particular, with a view to developing the Global Integrated Ship Information System (GISIS). Meanwhile, Cariou and Wolf (2011) used data from the Swedish Maritime Administration (1996-2001) to determine how ship characteristics influence the interval between two consecutive PSC inspections and the number of deficiencies detected during such inspections. They also investigated whether a ship that has undergone PSC inspection at a given time subsequently presents a reduction in the total number of deficiencies detected in the next inspection. They found that a ship's age, type and flag of registry were significant predictors (Cariou and Wolf 2015).

$\mathrm{Li}$ and Zheng (2008) studied the effectiveness of PSC and the methods adopted in regional PSC agreements for selecting ships for inspection; their study confirmed that the enforcement of PSC is effective in improving ship safety levels in maritime transport. More recent and novel studies include those by Bang (2012) and Li et al. (2014), who explored the dependencies between PSC inspections and a ship's involvement in accidents and incidents using Bayesian networks based on inspection, accident and incident data, with two alternative algorithms.

Other important developments in this field in 2014 have included the work of the Sub-committee on Implementation of IMO Instruments (IMO 2014) and documents issued by the Paris MoU Secretariat (Paris MoU 2008 to 2013).

Although Wu et al. (2014) have studied specific aspects of inspection (such as evaluating the effectiveness of emergency fire drills or PSC inspections on board), only Knapp and Franses (2007b) have conducted a general analysis about the influence of the professional profile of inspectors and the results of inspections. They concluded that there are differences in the average probabilities of detention based on inspector's background, but it was necessary, a further insight in order to make a final conclusion on the subject in question.

\subsection{The new inspection regime}

The Paris MoU was also the first in establishing a method for selecting the vessels to be inspected. The original method of selection started from the information already available on the vessel; this makes clear the importance of all the agreements having their own system for transmitting vessel data throughout their network. In the case of the Paris MoU, there were two initial procedural criteria for the selection of vessels for inspection: first that the vessel was already listed in the category 'Vessel for priority inspection' and second that it had a high 'General selection factor'.

Since the entry into force of the NIR at the beginning of 2011, each ship in the information system is assigned a ship risk profile, which determines its priority for 
possible inspection, the maximum interval between inspections and the scope of the inspection. All ships in the information system are categorised either as high, standard or low risk (HR, SR or LR) based on generic and historical parameters. The ship's risk profile is recalculated daily taking into account changes in the more dynamic parameters such as age, the 36 months history and company performance. Recalculation also occurs after every inspection and when the applicable performance tables for Flags and Recognized Organizations (RO) are changed.

Based on a ship's risk profile, the inspection and selection scheme determine the scope, frequency and priority of inspections (Payoyo 1994; Bang 2012; Piniella et al. 2000).

\section{The role of the PSC officers}

\subsection{Minimum criteria for inspector}

Inspectors must, as a minimum, have the following:

(a) Appropriate qualifications from a marine or nautical institution and relevant seagoing experience as a certified ship officer, holding or having held a valid STCW II/2 or III/2 certificate of competency not limited in terms of the operating area or propulsion power or tonnage (with a maritime experience of at least 5 years, including periods served at sea as officers in the deck- or engine-department respectively, or as a flag State inspector or as an assistant Port State Control inspector. Such experience shall include a period of at least 2 years at sea as a deck or engine officer) or

(b) Passed an examination recognised by the competent Authority as a naval

(c) Architect, mechanical engineer or an engineer related to the maritime fields and worked in that capacity for at least 5 years or

(d) A relevant university degree or equivalent and have properly trained and qualified as ship safety inspectors

In addition, inspectors must have the following:

- Completed a minimum of 1 year service as a flag-State inspector either dealing with surveys and certification in accordance with the Conventions or involved in the monitoring of the activities of recognised organisations to which statutory tasks have been delegated or

- Gained an equivalent level of competence by following a minimum of 1 year field training participating in Port State Control inspections under the guidance of experienced Port State Control officers

\subsection{The legal basis of PSC inspections within the framework of the European Union}

The legal basis is the European Directive 2009/16/EC on Port State Control replaced Directive 95/21/EC and established a new system, which was transposed into Spanish law by Royal Decree 1737/2010 (EU 2009). 
One of the aims of the new regulations was to achieve equal EU member state participation in the envisaged comprehensive inspection system by sharing the volume of inspections evenly among member states. Another crucial goal was to standardise ship detention criteria and inspection regulations and procedures in order to achieve uniform application in all ports and thus prevent ships from choosing particular ports in order to elude more rigorous control by the marine authorities. The directive also toughened the criteria for refusing community port access to ships that present a clear hazard to maritime safety and the marine environment. Such refusal can now become permanent if the ship operator persistently fails to take corrective actions following several refusals of access.

The inspection commitments for each member state are determined by calculating the average number of inspections in the last 3 years. The resulting figure is taken to represent the total number of ships to inspect by all $\mathrm{MoU}$ signatories, and this number is then distributed among the member states in proportion to the calls made in each country in the last 3 years (Table 1).

Pursuant to article 22 of Directive 2009/16/EC, amended by Directive 2013/38/EU, inspections can only be carried out by inspectors who fulfil the qualification criteria specified in Annex XI and who are authorised to carry out PSC by the competent authority, although they may be assisted by any person with the required expertise. In addition, all inspectors must carry a personal document in the form of an identity card issued by their competent authority.

The article further stipulates that inspectors must neither have any commercial interest in the port of inspection or in the ships inspected nor can they be employed by, or undertake work on behalf of, non-governmental organisations which issue statutory and classification certificates or which carry out the surveys necessary for the issue of those certificates to ships.

The same article also establishes that EU member states shall ensure that the competence of inspectors and their compliance with the minimum criteria referred to in Annex XI are verified and that the inspectors have received appropriate training in relation to changes to the PSC system applied in the community as laid down in this directive and amendments to the conventions. To this end, an EU Commission shall develop and promote a harmonised community scheme for the training and assessment of competences of PSC inspectors by member states.

\section{The case study of the Spanish Maritime Administration}

\subsection{Inspectors and inspections in the Spanish Maritime Administration}

The national port system in Spain comprises 44 ports of strategic importance that handle a high annual volume of traffic. Although there are other ports in Spain, these do not cater for international traffic and therefore do not carry out PSC inspections.

There are four professional profiles in Spain that comply with Annex XI of the Directive: naval architect, captain of the merchant navy, chief engineer and radio officer. These can be professional qualifications, in accordance with the STCW Agreement, or university degrees that have entailed the appropriate training. There is no specific degree in Spain in maritime inspection, although this is contemplated in the directive and may exist in other countries. 
Table 1 Inspections: commitment and performance

\begin{tabular}{|c|c|c|}
\hline MoU member states & Inspections target & Inspections performed \\
\hline Belgium & 1401 & 971 \\
\hline Bulgaria & 331 & 528 \\
\hline Canada & 819 & 835 \\
\hline Croatia & 296 & 260 \\
\hline Cyprus & 273 & 125 \\
\hline Denmark & 445 & 382 \\
\hline Estonia & 179 & 185 \\
\hline Finland & 344 & 316 \\
\hline France & 1520 & 1225 \\
\hline Germany & 1403 & 1424 \\
\hline Greece & 1028 & 990 \\
\hline Iceland & 66 & 62 \\
\hline Ireland & 393 & 234 \\
\hline Italy & 2034 & 1706 \\
\hline Latvia & 225 & 246 \\
\hline Lithuania & 168 & 182 \\
\hline Malta & 230 & 204 \\
\hline Netherlands & 1913 & 1583 \\
\hline Norway & 561 & 594 \\
\hline Poland & 414 & 432 \\
\hline Portugal & 576 & 445 \\
\hline Romania & 512 & 776 \\
\hline Russian Federation & 877 & 956 \\
\hline Slovenia & 242 & 240 \\
\hline Spain & 1759 & 1727 \\
\hline Sweden & 722 & 356 \\
\hline United Kingdom & 1743 & 1541 \\
\hline
\end{tabular}

Source: authors' own elaboration from Paris MoU database

Spain has 92 PSC inspectors based at 29 harbour masters' offices from where they can inspect other terminals or ports where foreign ships dock to carry out operations. Table 2 shows the number of accredited inspectors at each harbour master's office, which have been grouped according to area (north, south, Mediterranean and the Canary Islands).

As can be seen in these two tables, there is neither direct relationship between the distribution of inspectors and port importance nor volume of traffic; rather, with the exception of the occasional port, their distribution is relatively uneven. Neither is there a logical distribution in relation to the demand for inspections; there are almost twice as many inspectors in the north as in the south or the Mediterranean. However, it is in these latter areas where the ports with the most traffic are located, such as Algeciras, Valencia and Barcelona. Not only are there 
more PSC officers in the north, but there is often also a higher number of maritime inspectors in general, including Flag State inspectors. The more inspectors there are attached to a given harbour master's office, the greater the possibilities for specialisation in any of the areas established by the Paris MoU, thus increasing the number of trained inspectors meeting the accreditation criteria.

In accordance with the NIR established in 2011, Spain has 92 PSC officers qualified to carry out $\mathrm{MoU}$ inspections. However, these are distributed unevenly around the country. It is therefore not surprising to find that an analysis of the number of inspections they had carried out revealed that only 36 of them had carried out more than 30 inspections (approximately 3 inspections per month). Table 3 shows inspectors ranked according to the number of inspections they have conducted in the past year: one inspector had even carried out over 100 inspections. Table 4 shows only the most experienced inspectors ( $>30$ per year), divided according to their qualifications. As can be seen, there is a clear predominance of captains and naval architects over chief engineers and radio officers.

According to Spanish Maritime Administration training requirements, inspectors must have the following:

- Carried out a minimum of between 15 and 25 inspections under the supervision of an accredited inspector

- Completed European Maritime Safety Agency (EMSA) online training courses on technical aspects, procedures and conduct in different situations, aimed at standardising inspection and criteria

- Completed the two Spanish Directorate General of the Merchant Navy (DGMM) training courses on basic aspects of MoU inspection, MoU documents and annexes, and relevant European and Spanish legislation

- Completed the week-long 'New Entrant Seminar' course delivered at EMSA headquarters in Lisbon. This is aimed at new inspectors from all member states and consists of workshops on correct procedure in real scenarios and cases

Once inspectors have successfully completed this stage, an identity card is issued, duly translated into English, containing the following information:

1. Declaration that the identity card has been issued by the DGMM

2. Name, surname and recent photograph of the holder

3. Unique, non-transferable identifier

4. Signature of the identity card holder

5. Declaration authorising the holder to carry out ship inspections on behalf of Port State Control

Accreditation is valid for 5 years and renewal is based on participation in a professional development scheme in which credits are awarded for successfully completed activities. This ensures that accreditation is limited solely to inspectors who carry out regular inspections and are up-to-date with modifications to MoU procedures and documents. 
Table 2 Number of Port State Control officers in Spain
Number

Harbour master's office

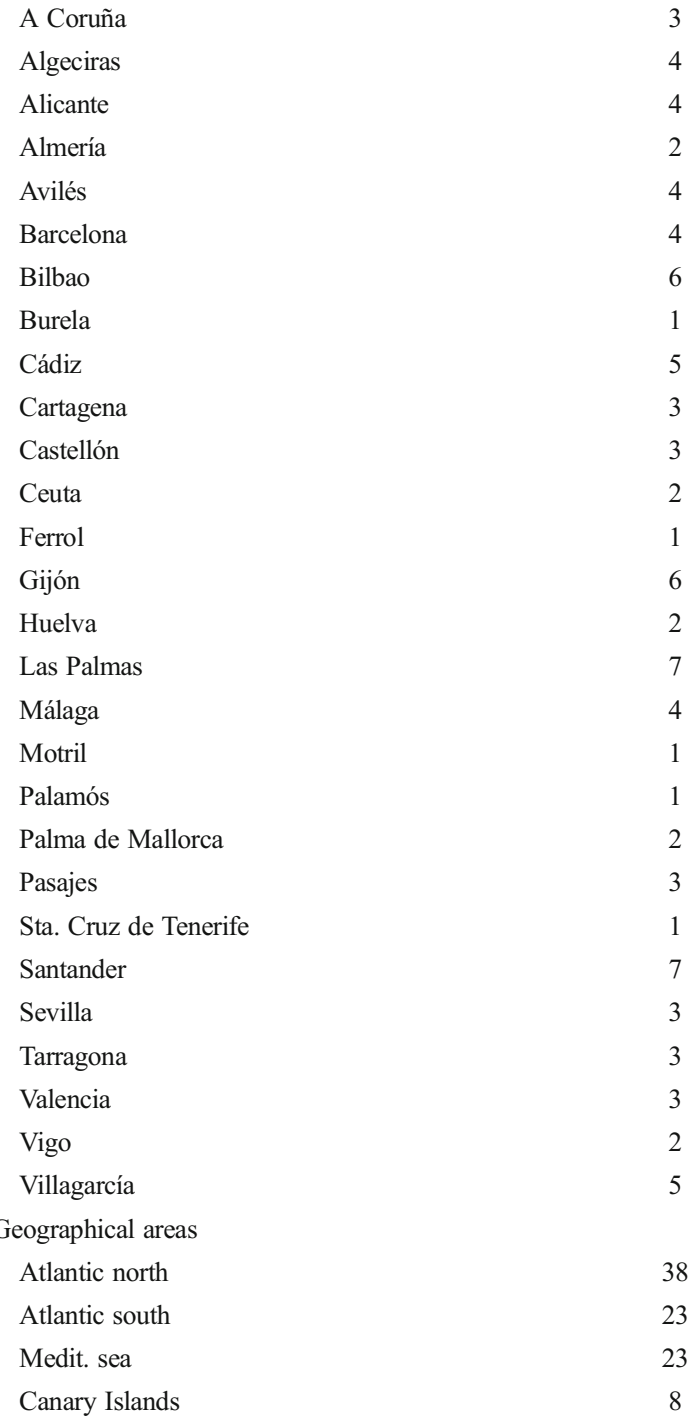

Source: authors' own elaboration

To renew their accreditation, inspectors must earn a minimum of 30 credits within 5 years. The professional development scheme includes a series of compulsory activities, which must be carried out by all MoU inspectors who wish to renew their accreditation, and optional activities that can be selected to obtain the necessary additional credits. Table 5 shows the activities and their credits. 
Table 3 Ranking of PSCOs

\begin{tabular}{cllc}
\hline Ranking & Profile & Harbour master's office & Number of PSCO \\
\hline 1 & Captain & Algeciras & 102 \\
2 & Naval architecture & Algeciras & 82 \\
3 & Captain & Castellón & 81 \\
4 & Naval architecture & Las Palmas & 68 \\
5 & Captain & Bilbao & 68 \\
6 & Naval architecture & Las Palmas & 67 \\
7 & Captain & Valencia & 67 \\
8 & Captain & Huelva & 63 \\
\hline
\end{tabular}

'Captain' profile includes all nautical degrees. Source: authors' own elaboration

PSCO Port State Control officer

\subsection{Deficiencies and detentions based on inspector's background}

\subsubsection{The survey: methodology and participants}

Given the preliminary study of Knapp and Franses (2007b), we focused our study, not only by inspectors but by groups of more than one inspector. Of the 92 accredited PSC inspectors in Spain, we selected 36 who had carried out a significant number of inspections ( $>30$ per year) in the year 2011. Data about the inspector's background were collected directly from each between 29 harbour masters' offices. We divided Spain into the four previously mentioned areas, and from each area we selected different inspector profiles. The number of 36 PSC officers was reduced to 15 because we did not take into account periodic inspections of ferries that regularly sail from Spain. Thus, we selected all inspections performed over 1 year by 15 inspectors with different professional profiles. The contact was made first by phone and then the data were used by the database THETIS. The sample finally included 387 inspections, accounting for $21.5 \%$ of all those carried out that year. Table 6 shows the general profile of these inspections by deficiencies detected.

We looked at all possible combinations of the four professional profiles, bearing in mind that inspections may be carried out individually or by a team, and established a coding system, as shown in Fig. 1. For example, code 2101 represents a team inspection carried out by 2 captains, 1 chief engineer and 1 radio officer, but without

Table 4 Number of PSCOs with more than 30 inspections

\begin{tabular}{lc}
\hline Profile & Number of PSCO \\
\hline Captain & 16 \\
Radio officer & 2 \\
Chief engineer & 4 \\
Naval architecture & 14 \\
\hline
\end{tabular}

'Captain' profile includes all nautical degrees. Source: authors' own elaboration

PSCO Port State Control officer 
Table 5 Spanish PSCOs professional development scheme

\begin{tabular}{lc}
\hline & Score \\
\hline Compulsory activities & \\
MoU inspections & \\
10 per year & 5 \\
25 per year & 10 \\
40 per year & 20 \\
Training module of procedures & 5 \\
Optional activities & \\
Courses/workshops & \\
EMSA refreshing course & 10 \\
MoU procedures workshop & 5 \\
MoU expert course & 5 \\
National refreshing course & 5 \\
National workshop & 5 \\
Training module of procedures & 5 \\
\hline
\end{tabular}

Source: authors' own elaboration

PSCOs Port State Control officers

a naval architect. With a view to further this issue and gain a clearer understanding on how inspector's background influences in the type or number of deficiencies of the vessels, what follows is a detailed examination of the replies received to our research.

\subsubsection{Results and findings}

In the first year after entry into force of the NIR, 1794 inspections were carried out in Spain. This was the highest number of inspections carried out by a single member state and accounted for $9.41 \%$ of the total number of inspections conducted throughout the entire MoU region. Italy followed closely behind with $9 \%$, and Holland and the UK with $8.42 \%$. An analysis of the statistics for the entire MoU area revealed that the percentage of inspections in which deficiencies were detected was distinctly higher than average in Spain, and the percentage of detentions was markedly higher, being almost double the average. This finding is open to several interpretations. One explanation might be that Spanish inspectors are more rigorous, perhaps because training and

Table 6 General profile of the inspections by deficiencies (sample of 387 inspections)

\begin{tabular}{lcc}
\hline & Number of inspections & Percentage \\
\hline 0 Deficiency & 123 & 32 \\
1 Deficiency & 35 & 9 \\
2 Deficiencies & 64 & 17 \\
3 Deficiencies & 36 & 10 \\
4 Deficiencies & 28 & 7 \\
5 Or more deficiencies & 97 & 25 \\
\hline
\end{tabular}

Source: authors' own elaboration 


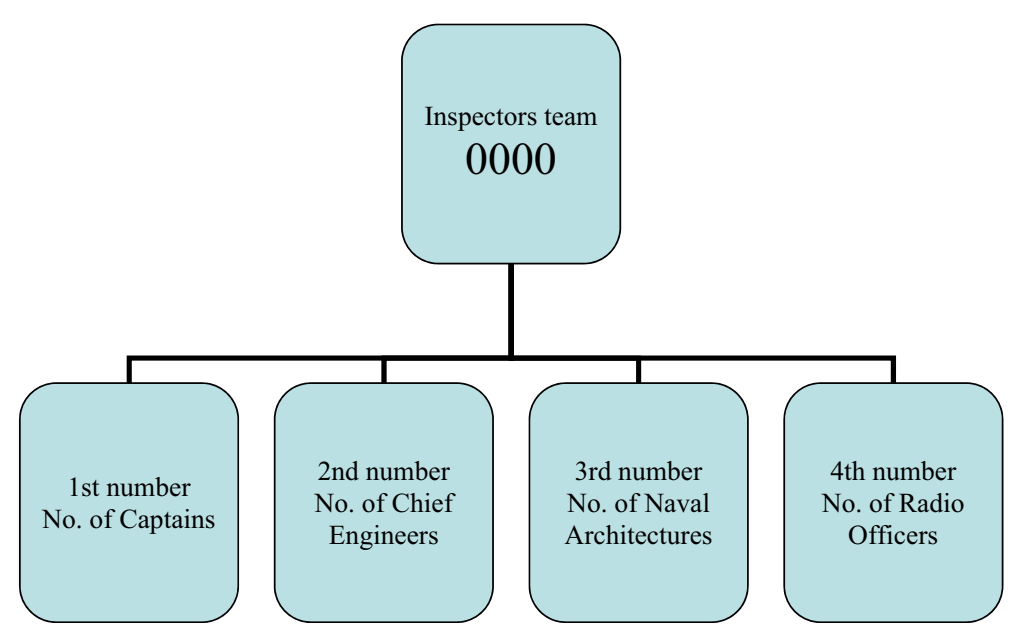

Fig. 1 Different possible combinations of the inspections

specialisation is better in Spain than in other member countries. Another explanation could be that due to Spain's strategic position, among other factors, the ships calling in Spanish ports may present more deficiencies in terms of their condition, crew or equipment. Spain ranks highest for total number of detentions, with 122 ships detained in the year under study.

No deficiencies were found in 123 of the 387 inspections analysed. The data showed that most inspections where no deficiencies were detected $(85 \%)$ had been carried out by only one inspector, irrespective of profile, indicating that the number of deficiencies detected is lower when inspections are carried out by a sole inspector.

To determine possible differences by professional profile, we analysed the results of the four combinations $(1000,0100,0010$ and 0001) that represent inspections performed by a single inspector, irrespective of profile. Next, we limited our analysis to inspections that corresponded to one of these combinations, namely, inspections carried out by just one inspector. The results are shown in Fig. 2.

We also analysed the most prevalent or common types of deficiency by each of these four profiles. The deficiencies were grouped and the results are shown in Fig. 3.

As can be seen, when chief engineers carried out inspections alone, they detected a high number of deficiencies related to propulsion. Naval architects detected a similar but slightly lower proportion of deficiencies in this area, but the percentage detected by captains was much lower. Captains detected a higher number of deficiencies than other profiles in aspects that are more closely related to a nautical qualification, such as lifesaving appliances, ship safety, and living and working conditions aboard.

With modern advances in electronic technology, satellite communication and computers, the radio officers are going into extinction. Radio inspectors do not have seagoing experience. However, nautical schools still train radio officers and they can become PSC officers according to the mentioned Annex XI of the Directive 2009/16/ EU, amended by Directive 2013/38/EU. Nonetheless, it is also interesting to note that although radio officers have most expertise in radio communication deficiencies, there was no significant difference in the percentage of deficiencies they detected compared with the other three profiles. We also determined the profile or combination of profiles 

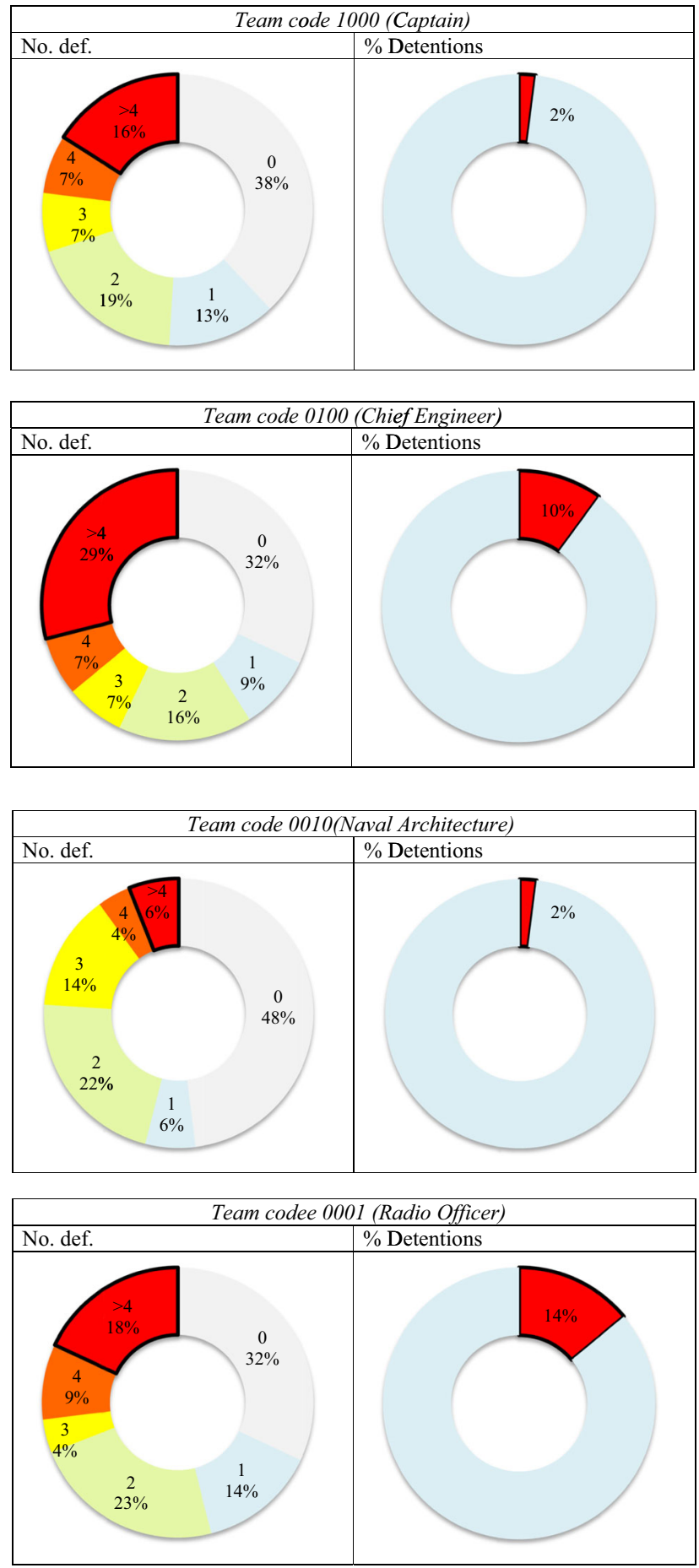

Source: Authors' own elaboration

Fig. 2 Number of deficiencies vs professional profiles 
Fig. 3 Types of deficiencies for each of those four profiles a)

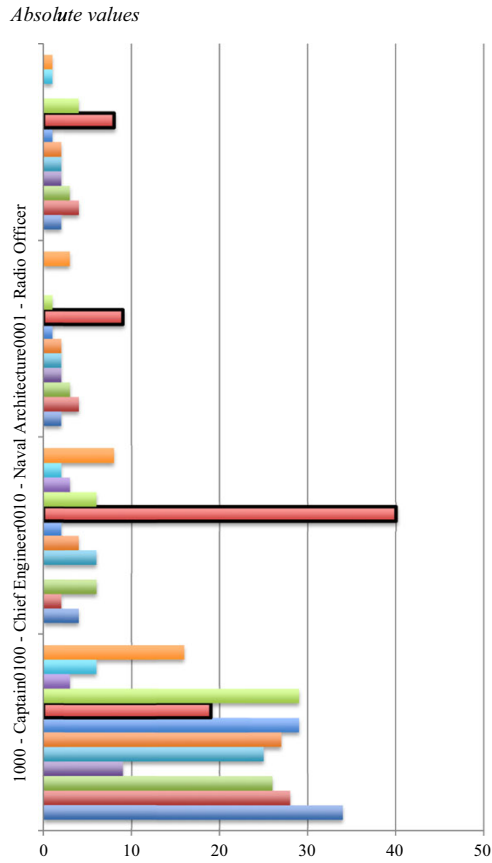

b) Stacked bar chart (100\%)

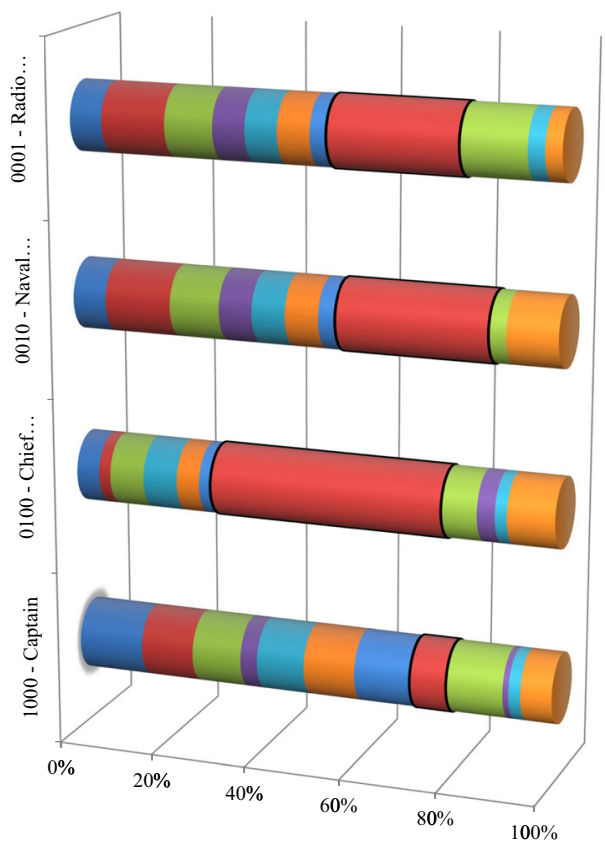

Source: Authors' own elaboration
=Other

$\varpi$ ISPS

$=$ ISM

- Pollution prevention

口Propulsion and auxiliary machinery

=Life saving appliances

$=$ Working and Living Conditions

=Fire Safety

= Radio

Communication

-Safety of

Navigation

-Structural Condition

=Certificates \&

Documentation 
Fig. 4 Team and rate of detentions

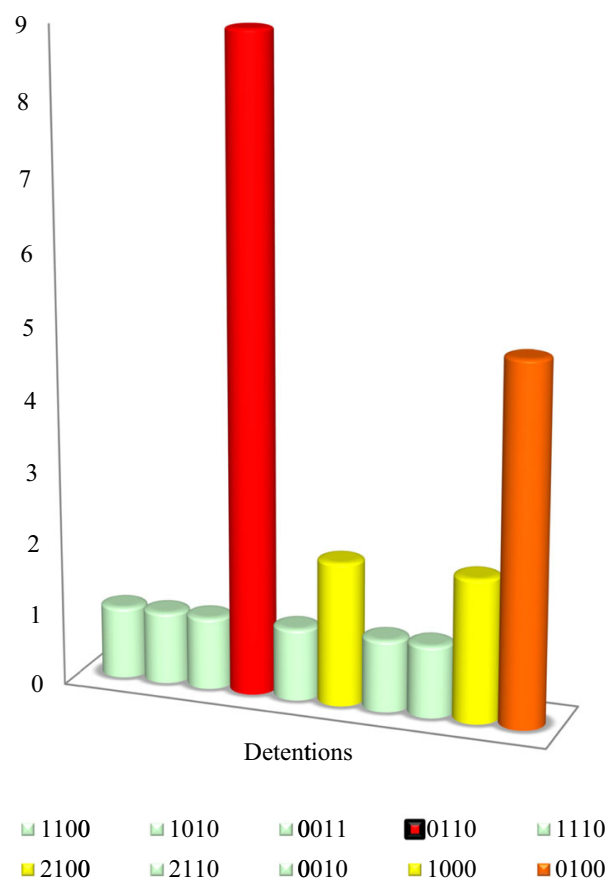

Source: Authors' own elaboration

with the highest rate of detentions in the 387 inspections sampled, bearing in mind that the total number of detentions in this sample was 27. As can be seen in Fig. 4, by far the most detentions were made by profile 0110 (naval architect and chief engineer conducting an inspection together), followed in second place by the profile of chief engineer when inspecting alone. These data clearly show that ships are much more likely to be detained when a chief engineer forms part of the inspection team.

We also analysed the type of ship most frequently detained in the sample studied and found that this corresponded to general cargo ships, which accounted for 21 out of 27 detentions. This trend coincides with that of the MoU region as a whole, where general cargo ships are also the most frequently detained type of vessel. An analysis of our sample also revealed differences between harbour master's offices regarding application of PSC criteria. Whereas some considered certain deficiencies to justify detention, the majority did not. One of the objectives of the initial entry and professional development courses for PSC officers is to standardise criteria in given situations, and these have even been codified. Furthermore, the work of the Directorate General of the Merchant Navy is also aimed towards standardisation. Nevertheless, some harbour master's offices detect a higher than average number of deficiencies per inspection and appear to be more stringent when assessing possible defects in a ship or its crew that could be considered as deficiencies.

In relation to the previous study of Knapp and Franses (2007b), we perceive some differences and some similarities: our study is quantitatively smaller but it covers possible cases of inspections carried out by more than one inspector, and it is 
focused on a single maritime administration, so that the data can be more homogeneous. Nevertheless, the main qualitative findings of Knapp and Franses (2007b) coincide with our national survey: the probability of detention of inspectors with an engineering background seems to be slightly higher compared with a nautical background.

\section{Conclusions}

Spain is responsible for a relatively high percentage of the deficiencies detected and detentions imposed in the European Union and consequently in the Paris MoU region. Further national studies are required to validate the conclusions of the present study; however, unlike general data on detained ships by country or deficiency code, national data are unfortunately not publicly available. We can conclude that there are differences but, as other authors' research stated, more analysis are required for other maritime administrations.

Nevertheless, our case study revealed that there was neither direct relationship between the number of inspectors allocated to ports and port traffic or importance nor were inspectors distributed evenly by professional profile. Neither European Directive 2009/16 nor the MoU guidelines on inspections make a distinction between types of professional profile nor establish the number of inspectors that should form an inspection team. In practice, however, all inspectors will be better equipped to evaluate some types of deficiency more than others according to their individual academic training and experience on ships. The data reported here clearly evidence the need for multidisciplinary teams, something that is contemplated in the MoU guidelines but is not mandatory. Teams are more likely to detect deficiencies on ships and also allow for joint decision-making, which is especially useful in the case of problematic or substandard ships. Our argument is clearly supported by the correlation we found between deficiencies detected and professional profile.

Our conclusions highlight the limitations of the NIR, given that variations in inspection stringency and results determine the interval between a ship's inspections. Thus, if an inspection team fails to apply inspection criteria appropriately, conducting a less than rigorous inspection in which few deficiencies are detected, a ship in poor condition may receive a favourable result. In consequence, not only the ship but also the ship-owning company, the flag State and the classification society will be granted a longer interval between inspections.

\section{References}

Aguilar S (2008) Evolución del Régimen de Sanciones y del Port State Control. Universitat Politècnica de Catalunya, Barcelona

Alcázar JA, Piniella F (2001) La Prevención de Siniestros Marítimos a través del Estado Rector de Puerto. Universidad de Cádiz, Cádiz

Bang H-S (2012) Recent developments in regional memorandums of understanding on Port State Control. Ocean Dev Int Law 43:170-187. doi:10.1080/00908320.2012.672293

Batalden BM, Sydnes AK (2013) Maritime safety and the ISM code: a study of investigated casualties and incidents. WMU J Marit Aff 13:3-25. doi:10.1007/s13437-013-0051-8 
Cariou P, Wolff FC (2011) Do Port State Control inspections influence flag- and class-hopping phenomena in shipping? J Transp Econ Policy 45:155-177

Cariou P, Wolff FC (2015) Identifying substandard vessels through Port State Control inspections:a new methodology for concentrated inspection campaigns. Mar Policy 60:27-39. doi:10.1016/j.marpol.2015. 05.013

Chatzirigopoulou M (2010) Port state control: legal basis. Erasmus Universiteit, Rotterdam

EU (2009) Directive 2009/16/EU, of the European Parliament and of the Council, of the 23rd April, on the control of ships by the Port State Control amended by Directive 2013/38/EU.

IMO (2014) Sub-Committee on Implementation of IMO Instruments (III): Agenda item 6-harmonization of Port State Control activities. Agenda item 7-PSC guidelines on seafarers' hours of rest and PSC guidelines in relation to the Maritime Labour Convention, 2006. Agenda item 8-development of guidelines on Port State Control under the 2004 BWM Convention. IMO Pub, London

IMO (2012) Procedures for Port State Control: Resolution A.787(19), as amended by Resolution A.882(21). IMO Pub, London

IMO (2001) Port State Control, model course 3.09. IMO Pub, London

Kidman P (2003) Port state control: a guide for cargo ships. Intercargo, London

Knapp S (2004) Analysis of the maritime safety regime: risk improvement possibilities for the Port State Control target factor (Paris MoU). Msc. Thesis in Maritime Economics and Logistics, EUR

Knapp S, Bijwaard GE (2009) Analysis of ship life cycles-the impact of economic cycles and ship inspections. Mar Policy 33:350-359. doi:10.1016/j.marpol.2008.08.003

Knapp S, Franses PH (2007a) Econometric analysis on the effect of port state control inspections on the probability of casualty. Mar Policy 31(4):550-563. doi:10.1016/j.marpol.2006.11.004

Knapp S, Franses PH (2007b) A global view on port state control-econometric analysis of the differences across port state control regimes. Marit Policy Manage 34:453-483. doi:10.1080/030888307015852217

Knapp S, Franses PH (2008) Econometric analysis to differentiate effects of various ship safety inspections. Mar Policy 32(4):653-662. doi:10.1016/j.marpol.2007.11.006

Knapp S, Franses PH (2010) Comprehensive review of the maritime safety regimes: present status and recommendations for improvements. Transport Rev 30(2):241-270. doi:10.1080/01441640902985934

Knapp S, Van de Velden M (2009) Visualization of differences in treatment of safety inspections across Port State Control regimes: a case for increased harmonization efforts. Transport Rev 29(4):499-514. doi:10. 1080/01441640802573749

Kuronen J, Tapaninen U (2010) Evaluation of maritime safety policy instruments. WMU J Marit Aff 9(1):4561. doi:10.1007/bf03195165

Li KX, Yin J, Fan L (2014) Ship safety index. Transp.Res.A 66:75-87

Li KX, Zheng H (2008) Enforcement of law by the Port State Control (PSC). Marit Policy Manage 35(1):6171. doi:10.1080/03088830701848912

Özçayir ZO (2004) Port state control. Lloyds Press, London

Payoyo PB (1994) Implementation of international conventions through port state control: an assessment. Mar Policy 18:379-392. doi:10.1016/0308-597X(94)90034-5

Paris MoU (2008 to 2013) Annual reports: https://www.parismou.org/publications-category/annual-reports

Piniella F, Pérez C, De la Cruz AG (2000) Statistical analysis of PSC inspections: inefficiency or inadequate procedures? In: "New maritime impulses in the presence of a new century". Proceedings 2nd International Congress on Maritime Technological Innovations and Research. Cádiz, Spain 1:78-88

Psaraftis HN (2002) Maritime safety: to be or not to be proactive. WMU J Marit Aff 1(1):3-16. doi:10.1007/ BF03195022

Schröder-Hinrichs JU, Hollnagel E, Baldauf M (2012) From Titanic to Costa Concordia - a century of lessons not learned. WMU J Marit Aff 11:151-167. doi:10.1007/s13437-012-0032-3

Veiga JL (2002) Safety culture in shipping. WMU J Marit Aff 1(1):17-31. doi:10.1007/BF03195023

Wu J, Jin Y, Fu J (2014) Effectiveness evaluation on fire drills for emergency and PSC inspections on board. TransNav 8(2):229-236 